\title{
Agricultural Plants and Their Antimicrobial Activities - A Mini Review
}

\author{
Sujata Mandal and Sheldon Q Shi* \\ Mechanical Engineering Department, University of North Texas, US
}

*Corresponding author: Sheldon Q Shi, Mechanical Engineering Department, University of North Texas, USA

To Cite This Article: Sujata Mandal and Sheldon Q Shi, Agricultural Plants and Their Antimicrobial Activities - A Mini Review. 2020 - 11(1). AJBSR.MS.ID.001615. DOI: 10.34297/AJBSR.2020.11.001615.

Received: 眥 October 11, 2020; Published: 眥 December 14, 2020

\begin{abstract}
Agricultural plants are rich in antioxidants and can be effectively used as antimicrobial agents. This review emphasizes the role of plants such as hemp, kenaf, jute, flax, and sisal that contain many bioactive compounds. They are known for antimicrobial, which provides further insight towards a better environment, health, and prevention from infectious diseases.
\end{abstract}

Keywords: Agricultural plants; phytochemicals; antimicrobial activity

\section{Introduction}

Agricultural plants are major sources of natural fibers. Plants contain many bioactive compounds and are a great source of antimicrobial agents [1]. Microbial contamination poses a serious threat to human health Plants with medicinal values have always been effective to cure different diseases caused by microorganisms. Centers for Disease Control and Prevention (CDC) has reported that $90 \%$ of foodborne human illness is attributed to bacteria. The most important bacterial diseases reported through transmitted water are cholera, typhoid fever, and bacillary dysentery [2].

Some common pathogens such as E. coli, S. aureus, and B. subtilis exhibit increased resistance to different antibiotics [3]. World Health Organization (WHO) has reported about $80 \%$ of the population from developing countries relies on traditional medicinal plants [4]. The emergence of multiple drug-resistant bacterial strains and fungal pathogens due to the indiscriminate use of antibiotics has generated a considerable interest among the researchers to investigate potent and alternative plants derived drugs [5,6]. Hemp, kenaf, jute, sisal, and flax are some of the agricultural plants containing lignocellulosic fibers, also called natural fibers. The main objective of this mini review is to explore the utilization of the above natural fibers based on their antimicrobial efficacy.

\section{Fiber Source and Fiber type}

Agricultural plants are producers of natural fibers and are classified into two broad categories viz primary plants and secondary plants. Plants that are cultivated due to their fiber content are known as primary plants while plants that are grown due to their by-product are called secondary plants. Hemp, kenaf, jute, sisal, and flax are some examples of primary plants while coir, pineapple oil, palm fall under the category of secondary plants. Commonly there are six types of natural fibers- bast fibers (hemp, kenaf, jute, flax), leaf fibers (pineapple, sisal), core fibers (hemp, kenaf, jute), reed fibers (wheat, rice, corn), and other types of woody fibers $[7,8]$.

\section{Bioactive Constituents of Fiber Plants}

Agricultural plants produce a whole series of bioactive components termed secondary metabolites. These are organic molecules that appear as intermediate or end products of secondary plant metabolism that exhibit antimicrobial activity $[1,9,10]$. Bioactive molecules can inhibit the growth of pathogens as well as have no or very little toxicity to the host cell. Phenols, polyphenols, terpenoids, alkaloids, cannabinoids, lectins, essential oils tannins, quinones, and polypeptides are some of the fundamental and essential antimicrobial phytochemicals present in plants $[1,11]$. 
Phenolic acid, flavones, flavonoid, and tannins are some of the beneficial bioactive molecules which are included in phenols and polyphenols $[1,12]$.

Phenols and polyphenols are the simplest bioactive phytochemicals. Quinones are highly reactive and are the source of stable free radicals which has high potential inactivation towards bacteria. The flavonoid, compounds have the phenolic structure and it has shown inhibitory effects not only towards bacteria also towards viruses like respiratory syncytial virus (RSV) and HIV $[1,13,14,15,16]$. The general formula of Terpenoids is C10H16 and they are highly active against Bacillus subtilis and Staphylococcus aureus $[17,18]$. Tannins are polymeric phenolic substances and they are found in almost every plant part. Several studies have reported that tannins are toxic to filamentous fungi, yeasts, and bacteria $[19,20]$.

\section{Antimicrobial Property of Natural Fibers and their Applications}

Hemp (Cannabis sativa L.) is an eco-friendly and multifunctional plant and it is the most predominantly investigated natural fiber plant. It is a dioecious woody, an herbaceous annual plant which can grow in a wide range of climate and soil condition. Cannabinoids are essential bioactive constituents that are present in hemp. Researchers have reported the antibacterial activity of hemp towards B. subtilis, E. coli, and S. aureus [21,22]. Hemp can be mixed with polymers such as chitosan, polylactic acid, polysulfone, polyethylene glycol, and can be used in various biomedical applications like in the form of implants and medical devices [23]. Cannabinoids and alkaloids in hemp can be used to prepare antibacterial drugs.

Kenaf, Jute, flax, and sisal have also been explored and exhibited some antibacterial activities. Kenaf (Hibiscus cannabinus), an annual herbaceous crop belongs to the Malvaceae family, is a valuable medicinal crop and are rich sources of cellulose. The plants possess a wider range of adaptation to environments, climates, soils, and distributed in Asia and Africa. Kenaf has significant medicinal properties including anticancer and antioxidants, and the kenaf leaves are used for the treatment of diabetes and cough. The antibacterial activity of Kenaf leaves and seed extracts against S. aureus and E. coli were reported [24]. Results revealed that kenaf seed extracts were very effective against both Gram-positive and Gram-negative bacteria [25,26]. The essential oil of kenaf had antifungal activity against Colletotrichum fragariae, Colletotrichum gloeosporioides, and Colletotrichum accutatum [27].

Jute (Corchorus olitorius L.) is one of the traditional plants that have great potential for medicinal purposes. Jute leaves are used as a diuretic, antipyretic, analgesic, and antimicrobial activities. The antibacterial activity of jute was demonstrated against Staphylococcus aureus, Micrococcus luteus, Bacillus cereus, Escherichia coli, Klebsiella pneumonia, Salmonella enterica, Salmonella typhi, and Enterobacter sp [28].

Flax (Linum usitatissimum) is an annual herb that belongs to the Linaceae family and cultivated worldwide. The inhibitory activity on bacteria of flaxseeds protein was reported against Enterococcus focal, Salmonella typhimurium, Escherichia coli, and S. aureus $[29,30]$.

Sisal (Agave sisalana Perrin) is a monocotyledonous plant belonging to the Agavaceae family. It is composed of $78 \%$ cellulose and $10 \%$ hemicellulose and used as herbal medicine to treat various diseases. Sisal extracts have demonstrated antimicrobial activity against Candida. albicans, Escherichia. coli, Staphylococcus aureus and Pseudomonas aeruginosa [31,32].

\section{Conclusions}

Medicinal plants have always been part of humanculture and have the potential to cure different diseases caused by microorganisms. Plants' secondary metabolites contain essential antimicrobial agents, exhibit a greater inhibitory effect against Gram-positive and Gram-negative bacteria. Plant derivatives have a major application in water treatment, textiles, food packaging, polymer composites, cosmetic industries, and biomedical applications. An extensive investigation focused on the identification, characterization and, antimicrobial efficacy of bioactive compounds of natural fibers is required.

\section{Acknowledgements}

This work was supported by the University of North Texas, Toulouse Graduate School -Graduate Research Award.

\section{Conflicts of Interest}

The authors declare there is no conflict of interest regarding the publication of this research manuscript.

\section{References}

1) Cowan, Marjorie Murphy (1999) Plant products as antimicrobial agents. Clinical microbiology reviews 12(4): 564-582.

2) Ashbolt NJ (2004) Microbial contamination of drinking water and disease outcomes in developing regions. Toxicology 198(1-3): 229-238.

3) Amee R, Manges MPH, James R, Johnson MD, Foxman B, et al. (2001) Widespread distribution of urinary tract infections caused by a multidrug-resistant escherichia coli clonal group. N Engle J Med 345(14): 1007-1013.

4) Bashir A, Ali N, Bashir S, Choudhary MI (2009) Biological activities of aerial parts of Tylophora hirsuta Wall. Afr J Biotechnol 8(18): 46274631 .

5) Cohen ML (1992) Epidemiology of drug resistance: implications for a post antimicrobial era. Science 257: 1050-1055.

6) Kafaru E (1994) Immense Help Formative Workshop. In Essential Pharmacology. $1^{\text {st }}$ edition. Publishers, Lagos, Nigeria. 
7) Shinoj S, Visvanathan R, Panigrahi S, Kochubabu M (2011) Oil palm fiber (OPF) and its composites: A review. Industrial Crops and products 33(1): 7-22.

8) Faruk O, Bledzki AK, Fink HP, Sain M (2012) Biocomposites reinforced with natural fibers: 2000-2010. Progress in polymer science 37(11): 1552-1596.

9) Rios JL, Recio MC (2005) Medicinal plants and antimicrobial activity. Journal of ethnopharmacology $100(1-2)$ : 80-84.

10) Shahidi S, Wiener J (2012) Antibacterial agents in textile industry. de Antibacterial Agents, V. Bobbarala, Ed, InTech, pp. 387-406.

11) Negi PS, Chauhan AS, Sadia GA, Rohinishree YS, Ramteke RS (2005) Antioxidant and antibacterial activities of various seabuckthorn (Hippophae rhamnoides L seed extracts. Food Chemistry 92(1): 119124.

12) Karas JA, Wong LJ, Paulin OK, Mazeh AC, Hussein MH, et al. (2020) The antimicrobial activity of cannabinoids. Antibiotics 9(7): 406

13) Evans SM, Cowan MM (2016) Plant products as antimicrobial agents. In Cosmetic and Drug Microbiology, CRC Press, PP. 227-254.

14) Pengsuparp T, Cai L, Constan, H, Fong HH, Lin LZ, et al. (1995) Mechanistic evaluation of new plant-derived compounds that inhibit HIV-1 reverse transcriptase. Journal of natural products 58(7): 1024-1031.

15) Barnard DL, Huffman JH, Meyerson LR, Sidwell RW (1993) Mode of inhibition of respiratory syncytial virus by a plant flavonoid, SP-303. Chemotherapy 39(3): 212-217.

16) Kaul TN, E Middletown, PL Ogra (1985) Antiviral effect of flavonoids on human viruses. J. Med. Virol 15: 71-79.

17) Ahmed AA, Mahmoud AA, Williams HJ, Scott AI, Reibenspies JH, et al. (1993) New sesquiterpene $\alpha$-methylene lactones from the Egyptian plant Jasonia candicans. Journal of natural products 56(8): 1276-1280.

18) Souza AB, Martins CH, Souza MG, Furtado NA, Heleno VC, et al. (2011) Antimicrobial activity of terpenoids from Copaifera langsdorffii Desf. against cariogenic bacteria. Phytotherapy Research 25(2): 215-220.

19) Scalbert A (1991) Antimicrobial properties of tannins. Phytochemistry 30(12): 3875-3883

20) Carvalho RS, Carollo CA, de Magalhães JC, Palumbo JMC, Boaretto AG, et al. (2018) Antibacterial and antifungal activities of phenolic compoundenriched ethyl acetate fraction from Cochlospermum regium (mart. Et. Schr.) Pilger roots: mechanisms of action and synergism with tannin and gallic acid. South African Journal of Botany 114: 181-187.

21) Khan BA, Wang J, Warner P, Wang $H$ (2015) Antibacterial properties of hemp hurd powder against E. coli. Journal of applied polymer science 132(10).
22) Cassano R, Trombino S, Ferrarelli T, Nicoletta FP, Mauro MV, et al. (2013) Hemp fiber (Cannabis sativa L.) derivatives with antibacterial and chelating properties. Cellulose 20(1): 547-557.

23) Ramakrishna S, Mayer J, Wintermantel E, Leong KW (2001) Biomedical applications of polymer-composite materials: a review. Composites science and technology 61(9): 1189-1224.

24) Salihu S, Otitolaiye CA, Hizbullah MU (2020) Invitro Antimalarial and Antibacterial Activities of Methanol Stem Bark Extract of Frankincense Tree (Boswellia dalzielii) and Leaves Extract of Kenaf (Hibiscus cannabinus). Genetics and Molecular Biology, Asian Journal of Biochemistry, p. 19-23.

25) Adnan M, Oh KK, Azad MOK, Shin MH, Wang MH, et al. (2020) Kenaf (Hibiscus cannabinus L.) Leaves and Seed as a Potential Source of the Bioactive Compounds: Effects of Various Extraction Solvents on Biological Properties. Life 10(10): 223.

26) Zakaria ZA, Zakaria ML, Amom Z, Desa MNM (2011) Antimicrobial activity of the aqueous extract of selected Malaysian herbs. African Journal of Microbiology Research 5(30): 5379-5383.

27) Kobaisy M, Tellez MR, Webber CL, Dayan FE, Schrader KK, et al. (2001) Phytotoxic and fungitoxic activities of the essential oil of kenaf (Hibiscus cannabinus L.) leaves and its composition. Journal of Agricultural and Food Chemistry 49(8): 3768-3771.

28) Yakoub ARB, Abdehedi O, Jridi M, Elfalleh W, Nasri M, et al. (2018) Flavonoids, phenols, antioxidant, and antimicrobial activities in various extracts from Tossa jute leave (Corchorus olitorus L.). Industrial Crops and Products, 118: 206-213.

29) Kaithwas G, Mukerjee A, Kumar P, Majumdar DK (2011) Linum usitatissimum (linseed/flaxseed) fixed oil: antimicrobial activity and efficacy in bovine mastitis. Inflammopharmacology 19(1): 45-52.

30) Tehrani MHH, Batal R, Kamalinejad M, Mahbubi A (2014) Extraction and purification of flaxseed proteins and studying their antibacterial activities. Journal of Plant Sciences 2(1): 70-76.

31) Su MA, Zheng LIU, Jin LIU (2012) Preparation of silver-loading antibacterial sisal fiber and its properties [J]. Dyeing \& Finishing, p. 5.

32) Santos JD, Branco A, Silva AF, Pinheiro CS, Neto AG, et al. (2009) Antimicrobial activity of Agave sisalana. African Journal of Biotechnology, $8(22)$. 